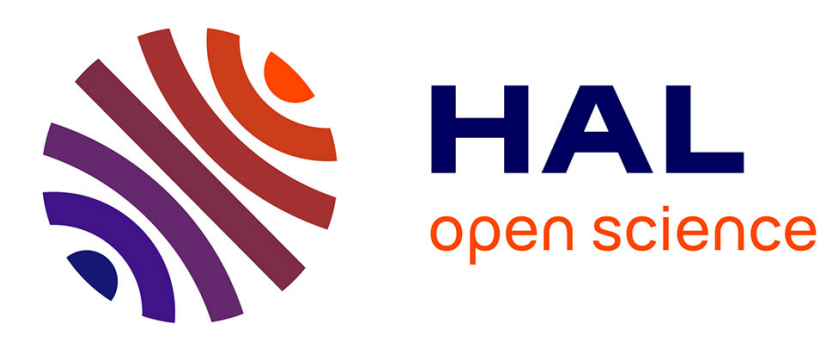

\title{
Mass Customization as a Productivity Enabler in the Construction Industry
}

Kim Noergaard Jensen, Kjeld Nielsen, Thomas Ditlev Brunoe

\section{To cite this version:}

Kim Noergaard Jensen, Kjeld Nielsen, Thomas Ditlev Brunoe. Mass Customization as a Productivity Enabler in the Construction Industry. IFIP International Conference on Advances in Production Management Systems (APMS), Aug 2018, Seoul, South Korea. pp.159-166, 10.1007/978-3-319-997049_20. hal-02164908

\author{
HAL Id: hal-02164908 \\ https://hal.inria.fr/hal-02164908
}

Submitted on 25 Jun 2019

HAL is a multi-disciplinary open access archive for the deposit and dissemination of scientific research documents, whether they are published or not. The documents may come from teaching and research institutions in France or abroad, or from public or private research centers.
L'archive ouverte pluridisciplinaire HAL, est destinée au dépôt et à la diffusion de documents scientifiques de niveau recherche, publiés ou non, émanant des établissements d'enseignement et de recherche français ou étrangers, des laboratoires publics ou privés. 


\title{
Mass Customization as a Productivity Enabler in the Construction Industry
}

\author{
Kim Noergaard Jensen, Kjeld Nielsen, Thomas Ditlev Brunoe \\ Department of Materials and Production, Aalborg University \\ $\mathrm{knj} @ \mathrm{mp} \cdot \mathrm{aau} \cdot \mathrm{dk}$
}

\begin{abstract}
Mass customization (MC) has improved productivity in the manufacturing industry, and it may be applicable in the construction industry, even though only limited literature for the implementation of MC is present.

This paper focus on how MC as a strategy can apply to the construction industry improving the overall productivity. This is done by analyzing the three fundamental capabilities of MC to determine their potentially contribution to improving the productivity relative to the well-known phases of a construction project. Any such contribution affect directly the productivity of a company as well as whole industry, and this paper points out where to seek for improvements to increasing the productivity in the construction industry by using MC as a strategy.
\end{abstract}

Keywords: Mass Customization, Productivity Improvements, Construction Industry, Project Phases.

\section{Introduction}

Most industries are subject to the increasing pressure coming from uncertainties of external factors like globalization, new market conditions, and new technology affecting the manufacturing and construction industry. Fulfilling customer specification through flexibly offering product families with many variants is the main market strategy [10], and customers' demands of verity in products leads to improvements of competitive advantages [20]. Fast introducing of new products have become the rule more than the exception, which may require considerable development investments and rollout costs [5]. The productivity in the Danish construction industry has doubled over fifty years, whereas the productivity of the manufacturing industry has increased six times (1966 to 2016) [9]. The same trend applies to countries in Scandinavian and Europe for the last twenty years indicating that the productivity gap is industry specific [15]. Productivity is measured as output per performed working hour for the entire economy [9].

Companies searches for initiatives meeting the competition, and the construction industry focus on lean construction, six sigma, TQM, digitalization, BIM, standardization trying to reduce costs in order to increase productivity [16], [22]. Construction productivity has been on the agenda for many decades revealing that project success depends on cost, time and quality as the most important key performance indicators. The con-

adfa, p. 1, 2011.

(C) Springer-Verlag Berlin Heidelberg 2011 
struction industry is subject for conflicting objectives as increasing demand for customized products, reduction of energy consumption, enhancement of cost efficiency; encouraging the construction industry to focusing on alternative improvement strategies [19]. New manufacturing philosophies, business processes reengineering, ICT, and development of production processes and correlated processes [11] are focus areas for improving the productivity. Some companies has undergone a transition process of offering customized products [24] "at a price near mass production" [3] under the strategy called mass customization [17] to meet the higher demand of product variety [1], [6], [14]. Manufacturing companies focus on modularization, prefabrication [21], configuration and changeable manufacturing [2], [25] aiming at exploiting the three fundamental capabilities of MC [21]:

1. Solution Space Development. Companies must understand their customer and their needs of products and services, by identifying valuable product attributers, and hereafter developing products and services that effectively can adapt to these individual requirements through standardization, product platforms, modularization, etc.

2. Choice Navigation. Companies must be able to guide their customer to identifying their own problems and solutions by selecting or configuring the product or service matching requirements, while minimizing complexity and burden of choice.

3. Robust Process Design. Companies must have a flexible and robust value chain design and mastering the ability to efficiently reuse or recombine existing organizational and value chain resources to fulfill the differentiated customers' need.

The essence of MC is the focus on customers problems, the requirement and demand of products and services by offering exactly enough variety in product range so nearly everyone finds what they want [19]. The success of a MC systems depends on external and internal factors, which justifies the use of $\mathrm{MC}$ as a competitive strategy and supports the development of MC systems; these six success factors are: 1) Customer demand for variety and customization must exist; 2) Market conditions must be appropriate; 3) Value chain should be ready; 4) Technology must be available; 5) Products should be customizable; 6) Knowledge must be shared [23].

The construction industry is characterized as delivering complex projects at various locations exposed to unpredictable weather conditions and seasonality, which differ from to the manufacturing industry [3], [4]. The construction industry's demand for customization in terms of individual architecture, function, quality, timeframe, environment, may seem challenging to handle with e.g. standardization, mass production, and modularization [7]. MC has not been explored in the construction industry, thus, only limited literature is currently present, but as the construction industry makes produces products with high variety, the utilization of the three fundamental capabilities of MC may result in higher productivity like in the manufacturing industry [7], [17].

This paper focuses on how the three fundamental capabilities of MC potentially can improve the productivity over the phases of a construction project in order to prioritize further improvement initiatives in the use of MC in the construction industry. 


\subsection{Research Questions}

An initial review of MC in the construction industry revealed only a limited amount of literature dealing with $\mathrm{MC}$, which indicate that further research is needed in order to understand clearly, how MC as a strategy can facilitate improving productivity of the construction industry.

\section{Research questions:}

The purpose of this paper is to analyze MC as a strategy improving the productivity of the construction industry by looking into the three fundamental capabilities of MC to clarify how they contributes to the productivity in the phases of a construction project. The research question of this paper is: RQ1: How can the three fundamental capabilities of MC potentially contribute to the productivity increase in the construction industry?

\section{Methods}

Research question 1 is addressed by analyzing the three capabilities of MC in order to clarify how they potentially can affect the productivity of a construction project. Entities in the value chain both individually and interconnected are of particular interest utilizing of the three fundamental capabilities of MC. Initially parties of a construction project will be defined, after which the phases of a typical construction project will be clarified in order to determine where the three fundamental capabilities of MC interfere.

\section{$3 \quad$ Result}

The entities involved in Architecture, Engineering and Construction (AEC) projects consist of architects, engineers, consultants and advisors; construction company and external parties working on site; suppliers of materials delivered to the site, tools and machinery applied on site; manufactures of prefabricated elements to be delivered on site; and the construction owner. Availability of standards and tools are the prerequisites for a successful cooperation between entities, and therefore the foundation for applying MC improving the productivity. Any construction project, can only be achieved by handling the customer's needs as an integrated process across the design and construction phases of a project involving entities of the value chain, which seems possible by using ICT and available standards (BIM/IFC) [15].

Construction projects are often structured individually from project to project, and from company to company seen from a management perspective. Nevertheless, there seems to be a certain conformity about four overall project lifecycle phases; design [D], construction [C] and operations [O], and demolition [D]. These phases may be subdivided into sub-phases, and further subdivided into activities, sub-activities and tasks, etc. However, this paper deals with the following six phases: 1) plan, involving management activities like planning, monitoring, leadership, etc., starting the project and evolving during the entire project; 2) design, including product development activities 
concerning architecture and engineering, 3) construct, comprising physical activities taking place off-site and on-site related to manufacturing, assembly, montage; 4) handover, dealing with activities associated with reviewing project deliverables meeting agreed contract; 5) maintenance, relating to daily operations/maintenance of the product; 6 ) demolition, is the final stage of a product including activities related to destruction and reusing. Some phases overlaps each other, and especially the planning phase seems to interfere with all phases during the entire project from cradle to grave as an iterative process changing character during the project lifecycle.

The three fundamental capabilities of MC will be mapped accordingly to these six phases clarifying where $\mathrm{MC}$ has a positive or negative contribution to productivity.

\subsection{Solution Space Development (SSD)}

As a part the Solution Space Development (SSD) a mass customizer must identify the needs of its customer, and define where the customers are different and where they care about the differences, e.g. product attributers clarifying what to offer. The foundation is a knowledgebase of preferences, needs, desires, satisfaction, motives of the potential customers and users of the products or services. However, this may seem as a fundamental change for ETO companies as it may limiting the product offerings to customers, which indeed should not be the case as the knowledgebase is dynamic and adaptable always trying to reflect the needs of the customers. The essential part is to understand the needs of the customers and to decide, whether and how these are being meet.

SSD includes three approaches to development capabilities: "Innovation tool kits", "Virtual concept testing", and "Customer experience intelligence" [21]; which are considered as guidance direction and not a limitation to the work related to clarifying the solution space that companies want to develop and deliver to the customers.

"Innovation tool kits, implies the software that enables large pools of customers to translate their preferences into unique product variants, allowing each customer to highlight possibly unsatisfied needs" [21]. Such solutions or toolkits will obviously help companies and customers strengthen their collaboration opportunities about project deliverables focusing their effort on correct fulfillment of needs, quality issues, and limitation of reworks caused by misunderstandings of design and requirements specifications. Therefore, this approach would potentially have a productivity impact on the phases: plan, design, construct.

"Virtual concept testing, covers an approach for efficiently submitting scores of differentiated product concepts to prospective customers via virtual prototype creation and evaluation" [21]. For the majority of the products developed by AEC projects are possible to be virtual illustrated and evaluated beforehand to strengthen the customer experience of the intended project deliverables increasing clarity of design and reducing misunderstandings leading to rework. Therefore, this approach would potentially influence the tasks related to the phases: plan, design, construct, and hand-over in terms of reducing hours spent.

"Customer experience intelligence, represent a tool for continuously collecting data on customer transactions, behaviors or experiences and analyzing that information to determine customer preferences" [21]. Establishing of such tools are evolving due to 
present data gathering and analytic possibilities, sensor technology for capturing data, and the increasing usage of Internet of Things (IoT). However, data gathering initiatives about the usage of the product as a whole or in terms of modules, equipment will increase knowledge about user behaviors or experiences to be used in terms of strengthen the collaboration process aiming at making better products at a lower time consumption leading to a potentially productivity increase in the phases: plan, design, and construct.

\subsection{Robust Process Design}

Robust Process Design (RPD) is the firms' capability reusing existing organizational and value-chain resources to deliver customer solutions with high efficiency and reliability, so increased variability in customers' requirements will not significantly influence the operational efficiency [18]. For ETO companies this include integration of business processes related to the engineering and the production value-chain involving internal and external entities of the supply chain. As MC is a value based concept, it is essential to integrate across the value chain to achieve full effect of MC [12], [23]. Thus, willingness and cooperation possibilities across the value chain is one of the success factors of application of MC, therefore standards and tools applicable within the construction industry is of particular interest. RPD cover three approaches to development capabilities: "Flexible automation", "Process modularity", and "Adaptive human capital" [21] considered as guidance issues rather than limitation of the work related to creating robust processes used to develop and deliver products to customer.

"Flexible automation, includes automation that is not fixed or rigid and can handle the customization of tangible or intangible goods" [21]. Each project is subject to a series of serial and parallel processes taking place in all phases without exception, e.g. activities necessary for making the design, the requirement specifications, and in general ensuring other mutual clearance of interests, or fulfilling manufacturing processes taking place on-site or off-site. Therefore, flexibility in processes and atomization of processes are enablers of customization in order to reducing time consumption potentially leading to a productivity increase in all of the six project phases.

"Process modularity, covers segmenting of existing organizational and value-chain resources into modules that can be reused or recombined to fulfill differentiated customers' needs" [21]. Any attempt to modularize whether it covers organizational or value-chain resources being able to efficiently handle customization and variation will provide readiness for serving customers' needs efficiently and thereby increase the productivity. Prefabrication has become popular mostly because of its ability to improve the productivity in terms e.g. increasing quality, decreasing cost, and accelerating speed of delivery, etc. Dedicated organizational flexible teams applied inside or outside the company are enablers of bringing key competences in play in terms of utilizing the right skills at the right time. The same advantages appears when rethinking the value chain into 'flexible modules' to be combined in order to serve customers' needs the most efficient way. Therefore, this approach indicate a productivity connection to primary the following phases: plan, design, and construct.

"Adaptive human capital, is about developing managers and employees who can deal with new and ambiguous tasks" [21]. Humans are the intellectual capital of the 
company ensuring any actions to happen and making the right decisions at the right time. Employees in the construction industry are used to deal with new and ambiguous tasks as this has always been the nature of the construction industry. However, the construction industry seems conservative in many ways, especially in terms of adapting new ways of doing things in particularly coming from the manufacturing industry like the MC strategy. Nevertheless, this adaptive attitude is a necessity to bring into play to successful implementing MC or parts of it for harvesting the productivity gains. Therefore, it can be argued that this approach apply indirectly to all phases.

\subsection{Choice Navigation}

Choice Navigation $(\mathrm{CN})$ is about supporting customer in identifying their needs, specifying the wanted solution using simple, effective and user-friendly product configuration system [13]. CN aims at finding the right level of choices as to many options can reduce customer value instead of increasing it [8] leading to postponing buying decision. The increasing development of new efficient and user-friendly IT solutions supporting the users in their decision-making process will optimize ETO companies' opportunities of presenting their solution space, which is beneficial for the customers decision making process, and for the ETO companies' transition process towards a higher ratio of the three $\mathrm{MC}$ capabilities. $\mathrm{CN}$ can be divided into three approaches to development capabilities: "Assortment matching", "Fast-cycle, trial-and-error learning", and "Embedded configuration" [21], and these approaches are considered as guidance and not necessary representing all issues related to $\mathrm{CN}$, also termed product configuration, as basis for taking in and handling new orders efficiently.

"Assortment matching, deals with software matching characteristics of an existing solution space (that is a set of options) with a model of the customer's needs and then makes product recommendations" [21]. Product configuration tools has evolved towards intuitive and user-friendly solutions enabling interactive user-dialog specifying and creating unique product configurations done in compliance with the solution space. Implementing such solutions require enormous effort, but the time savings are tremendous as it helps the customer and parties in the value chain during the entire configuration process potentially leading to e.g. reducing time consumption in the design phase, increasing quality, and reducing rework, thus it has positive effect on the productivity in the phases: plan, design, and construct.

"Fast-cycle, trial-and-error learning, is an approach that empowers customers to build models of their needs and interactively test the match between those models and the available solutions" [21]. Many customers have a strong idea of what they want, but having investigating possibilities enriching them during the clarifying process as they can play around with different options evaluating their needs. Such tools has a positive productivity effect in the phases: plan, design, and construct, as it takes the customer to a higher level of understanding, and clarifying their needs minimizing design misunderstandings e.g. saving time, increasing quality, and reducing rework.

"Embedded configuration, deals with products that "understand" how they should adapt to the customer and then reconfigure themselves accordingly" [21]. Many manufactures of homes and interior designers has created reconfigurable solutions in a way 
to accommodating many different purposes meeting various customers' needs. Such flexible and changeable approaches extend the usage and the functionality, and thereby the value of the products, since the customer may relate to multiple uses of the product. This may strengthen the competition position as it may lead to an easier decision making process for the customer, thus such products seems productivity neutral unless the embedded configuration concept allows fewer products.

Fig. 1 summarizes how the approaches to development capabilities of the three capabilities of MC [21] affect the productivity in the six phases of a construction project.

\begin{tabular}{|l|l|c|c|c|c|c|c|}
\hline & & \multicolumn{6}{|c|}{ Construction Industry - Project Phases } \\
\hline $\begin{array}{l}\text { Capabilities of } \\
\text { MC }\end{array}$ & $\begin{array}{l}\text { Approaches to development } \\
\text { capabilities }\end{array}$ & Plan & Design & Construct & Hand-over & Maintenance & Demolition \\
\hline $\begin{array}{l}\text { Solution Space } \\
\text { Development }\end{array}$ & Innovation Tool Kits & $\mathrm{X}$ & $\mathrm{X}$ & $\mathrm{X}$ & & & \\
\cline { 2 - 9 } & Virtual Concept Testing & $\mathrm{X}$ & $\mathrm{X}$ & $\mathrm{X}$ & $\mathrm{X}$ & & \\
\cline { 2 - 8 } & Customer Experience Intelligence & $\mathrm{X}$ & $\mathrm{X}$ & $\mathrm{X}$ & & & \\
\hline \multirow{2}{*}{$\begin{array}{l}\text { Robust } \\
\text { Process Design }\end{array}$} & Flexible Automation & $\mathrm{X}$ & $\mathrm{X}$ & $\mathrm{X}$ & $\mathrm{X}$ & $\mathrm{X}$ & $\mathrm{X}$ \\
\cline { 2 - 8 } & Process Modularity & $\mathrm{X}$ & $\mathrm{X}$ & $\mathrm{X}$ & & & \\
\cline { 2 - 8 } & Adaptive Human Capital & $\mathrm{X}$ & $\mathrm{X}$ & $\mathrm{X}$ & $\mathrm{X}$ & $\mathrm{X}$ & $\mathrm{X}$ \\
\hline \multirow{2}{*}{$\begin{array}{l}\text { Choice } \\
\text { Navigation }\end{array}$} & Assortment Matching & $\mathrm{X}$ & $\mathrm{X}$ & $\mathrm{X}$ & & & \\
\cline { 2 - 8 } & Fast-cycle, trial-and-error learning & $\mathrm{X}$ & $\mathrm{X}$ & $\mathrm{X}$ & & & \\
\cline { 2 - 8 } & Embedded Configuration & & & & & & \\
\hline
\end{tabular}

Fig. 1. Mapping capabilities approached to proiect phases

\section{Conclusion}

This paper deduce a potentially productivity connection from each of the development approaches of three fundamental capabilities of MC into the six phases of a construction project (fig. 1). Even though, it does not clarify how to harvest productivity gains it indicate that $\mathrm{MC}$ is applicable in the construction industry and it justify that further work along with the three capabilities of MC is beneficial to carry out.

\section{$5 \quad$ References}

1. Aigbedo, H.: A Note on Parts Inventory and Mass Customization for a TwoStage JIT Supply Chain with Zero-One Type of Bills of Materials. J. Oper. Res. Soc. 60(9), 1286-1291 (2009)

2. Andersen, A., Brunoe, T. D., Nielsen, K. et al.: Towards a Generic Design Method for Reconfigurable Manufacturing Systems - Analysis and Synthesis of Current Design Methods and Evaluation of Supportive Tools. Journal of Manufacturing Systems 42, 179-195 (2017)

3. Batchelor, R.: Henry ford, mass production, modernism, and design, Vol. 1. Manchester University Press (1994)

4. Bohnstedt, K. D.: Enabling Facilitation of Mass Customization Via Partnering in the Construction Industry. ,179-188(2014)

5. Chryssochoidis, G. M., \& Wong, V.: Customization of Product Technology and International New Product Success: Mediating Effects of New Product Development and Rollout Timeliness. J. Prod. Innovation Manage. 17(4), 268-285 (2000) 
6. da Silveira, G. J., Fogliatto, F. S., Fendyur, A.: Is Mass Customization a Global Phenomenon? Empirical Evidence from an Exploratory Study.

7. Dean, P., Tu, Y., Xue, D.: An Information System for One-of-a-Kind Production. Int J Prod Res 47(4), 1071-1087 (2009)

8. Desmeules, R.: The Impact of Variety on Consumer Happiness: Marketing and the Tyranny of Freedom. Academy of Marketing Science Review 2002, 1 (2002)

9. dst.dk: Dansk Statistik - Www.Dst.Dk. 2013 (2013)

10. ElMaraghy, H., Schuh, G., ElMaraghy, W. et al.: Product Variety Management. CIRP Ann. Manuf. Technol. 62(2), 629-652 (2013)

11. Fagerberg, J.: Technological Progress, Structural Change and Productivity Growth: A Comparative Study. Structural change and economic dynamics 11(4), 393-411 (2000)

12. Fogliatto, F. S., da Silveira, G. J. C., Borenstein, D.: The Mass Customization Decade: An Updated Review of the Literature. Int J Prod Econ (2012)

13. Franke, N., \& Piller, F.: Value Creation by Toolkits for User Innovation and Design: The Case of the Watch Market. J. Prod. Innovation Manage. 21(6), 401 415 (2004)

14. Haug, A., Ladeby, K., Edwards, K.: From Engineer-to-Order to Mass Customization. Management Research News 32(7), 633-644 (2009)

15. Jensen, K. N., Nielsen, K., Brunoe, T. D. et al.: Productivity, Challenges and Applying Mass Customization in the Building and Construction Industry. (2018)

16. Lisstrand, J., \& Sikell Lundin, P.: FÖR EN ÖKAD ANVÄNDNING AV DIGITALA VERKTYG I BYGGPRODUKTIONEN: En Studie Om Vad Som Krävs För Att Byggbranschen Ska Digitaliseras i Takt Med Omvärlden. (2017)

17. Pine, B. J.: Mass customization: The new frontier in business competition. Harvard Business School Press, Boston, Mass. (1993)

18. Pine, I., Joseph, B., Victor, B.: Making Mass Customization Work. Harv. Bus. Rev. 71(5), 108-117 (1993)

19. Piroozfar, P. A., \& Piller, F. T.: Mass customisation and personalisation in architecture and construction. Routledge (2013)

20. Salvador, F., Forza, C., Rungtusanatham, M.: How to Mass Customize: Product Architectures, Sourcing Configurations. Bus. Horiz. 45(4), 61-69 (2002)

21. Salvador, F., De Holan, P. M., Piller, F.: Cracking the Code of Mass Customization. MIT Sloan Management Review 50(3), 71-78 (2009)

22. Schevers, H., \& Drogemuller, R.: Converting the Industry Foundation Classes to the Web Ontology Language. ,73-73(2005)

23. Silveira, G. D., Borenstein, D., Fogliatto, F. S.: Mass Customization: Literature Review and Research Directions. Int.Journal of Production Economics 72, 1-13 (2001)

24. Walcher, D., \& Piller, F. T.: The customization 500. 1st edition edn. Lulu Press, Aachen (2011)

25. Wiendahl, H., ElMaraghy, H. A., Nyhuis, P. et al.: Changeable ManufacturingClassification, Design and Operation. CIRP Annals-Manufacturing Technology 56(2), 783-809 (2007) 